\title{
SPECIFIC FEATURES AND TYPES OF PRODUCERSHIP
}

\author{
Sayfulla Ikramov ${ }^{I}$ \\ ${ }^{1}$ IACU Faculty of Folk Art \\ Deputy Dean for Youth Affairs \\ High-class announcer, dubbing actor
}

ABSTRACT

This article discusses the emergence of the producer profession, producer activities, the skill of the producer, types of producer and its features

Keywords: producer, administrator, entrepreneur, impresario, manager, amateur.

\section{INTRODUCTION}

As a result of the rapid development of science (artistic thinking and data collection) and the emergence of new technologies, modern art has reached its highest creative stage. Nowadays, any stage play is a perfect system with its own «language", "code", and "symbol". To understand its language, its sign, certain intellectual knowledge is required. The real spectator must understand the alphabet of artistic creation, the artistic image, the language of the theater. modern art demands that artists should be as diligent as possible in creating and virtualizing each scene in their imagination in order to capture the audience's attention .

\section{MAIN PART}

Based on these requirements, the profession of producer emerged in the late nineteenth and early twentieth century's .The profession became popular and developed, first in the United States, then in Western Europe and elsewhere.

So, who is the producer? What does he do? Prior to the emergence of the producer profession, there were various professional orientations in the arts that performed certain functions of the producer.

For example:

- an administrator is responsible for carrying out the activities of all groups during the implementation of the project.

-an intrepeneur is in the field of theatrical art and has been involved in a one-rime personal theater project.

- an impresario- is to sell , to finish product, rent, find a place to rent, print tickets and distribute them.

-a manager- a referral worker who is not involved in the implementation of the project at the beginning.

The producer differs in that he is able to create an "idea" from all of the above areas.

The word producer (eng. producer.lot. producere) means to create, to produce. The producer manages ongoing projects in the field of art, in financial, administrative, technological and legal areas. In the creative process, in the implementation of the project, it spends its own funds put financial control by attracting funds from external sponsors.

\section{The origin of producership}

The producer profession began to take shape in 1910 in Hollywood. Initially, the producer responded to a creative, financial, organizational issue during the filming process. In this way, producers have a special place in American cinema. Renowned producer Irvin Talberg has a special place in American cinema. Following Talberg's death in return for his work in cinema, the USA film Academy established The Irvin Talberg Award .This award is given annually to the best producers .From year to year, the demand for producers has increased and this profession has spread to Western Europe .In particular, the demand for producers in pop shows, television and theatres has increased.

In the 19th century, the audience visited the theater for an actor, in the 20th century, they came to see the work of the director and in the 21 st century, they will rush to see the work of producer .It would be correct to call the rapidly evolving 21 st century " the producer theater age". It is this profession who chooses the work, invites the director and actors, and pledges his money. The success or failure of a play also depends on the producer.

Even today, the USA film company Hollywood is the world's largest film producer thanks to the work of producer. In this film industry well-known prodycers like David Sleznik, Jeyms Kemeron, B. Brukhaymer, Stiven Spilberg, Robert Zemiks, Devid Haymak, Kristin Vashon, Emmanuel Lyubeski, Lourens Vender succeed in creating film masterpieces.

The collaboration between the producer and the director has developed, and examples of co-creation towards ideas and goals have emerged. This led to the development of the production profession in all fields of art.

A producer is the author of a new work of art being created, and in the next process can be a manager, an organizer, sometimes a director, an impresario, or even a lead actor. In implementing the project idea, the producer selects a profitable actor, forms a team, selects a repertoire, organizes an advertising campaign and launches a mechanism. At the same time, the producer is responsible for the project idea.

\section{Types of the producer profession}

The producer profession is divided into several types and differs from each other. These are as follows :

1.Theater producer. 
2.Musuc producer.

3. Game producer

4.Movie producer

5.Television producer

1.Teatre producer- a theatre producer must have an understanding theatrical art, experience in directing and acting skills, and a good knowledge of theory and practice. A person who has never participated in the staging of a play in his life, who does not understand theatrical performance, is an amateur, not a producer.

Need a producer in theatrical art here? What for? The question arises. In today's market economy, it is necessary to be able to sell and advertise theatrical products. Creating a competitive theater is a modern requirement. The role of the producer in the implementation of this work is invaluable. In many world -famous theatres, producers are leading and making a significant contribution to the development of theatrical art. Along with theater directors, producers are actively involved in the artistic repertoire of theatrical repertoire.

The 21st century is becoming a century of real producer theater, as it is the producer who chooses the play , invites the director and actors, and attracts a large amount of money. But most fans of classical theater do not like this . However, they are forced to recognize the producers who are masters of their craft.

The basis of the producer profession is to find the project that audience needs. A job that does not require much effort from the outside requires serious preparation. Nowadays, professions like a good producer and a good director are rare professionals. The producer profession is based on human qualities and knowledge.

Once the producer has identified the goals and objectives while working on the play, he or she begins to do the organizational and financial work. Then the idea of the project is formed, the audience's interest is constantly monitored and their interests are identified.

The producer creates a calendar staging plan before starting each project. This plan clearly shows all the work that the producer will do on the project .In particular, the processes of economics, creativity, law and management and expressed. Well-crafted dramatic material and the director's work will help make this project a reality. In addition to knowledge of the field directing, a theater producer needs to know financial accounting.

2.Music producer- ( eng .music producer) in the process of recording, it means that the performers are responsible for their personality, image, and musical style. A music producer is a person who responds to the outcome of a music product. Their work is multifaceted. From the selection of musical materials to the writing process, he is in charge. The quality output of the music, the definition of the repertoire, responds to the overall idea of the project. The producer chooses the sound engineer, the editor, the assistants, sets the time in the studio and decides which musicians to invite. It is his task to fully disclose the creative ideas of authors.

The producer should be well aware of the possibilities of sounds .If he is producing live music, he is required to know the characteristics of all musical instruments, drums and circle.

Getting along with sound directors is a major task for a producer. A good piece of music will not be recorded if the sound director turned off the recording and turns it on only when the producer says so. The sound with the producer can witness the magic of creating music thanks to the collaborative ideological work of the directors. Before directing the music, the producer needs to know exactly what he or she wants to achieve in the recording industry and be able to clearly explain it to the studio staff. In the direction, the sound director reinforces the work has done so far. At this point, the producer decides on the technical style, assigning stylistic tasks to the sound director.

Music producers' profession is a complex, multi-level process that requires a great deal of time, time and patience from the producer as a creative-managerial person.

3. Game producer- first and foremost the computer must be familiar with its technology and the process of creating. Technology cannot be managed without knowledge .This field is very developed, especially in United States and Europe. Computer games are divided into intellectual development, militant, detective , sports recreation and entertainment games. The games will be designed for adults and children.

The producer should be able to find well- educated computer programmers to create these games and get interested in their idea. These games can be recorded as dusk or sent over the internet. Nowadays, the majority of game fans are taken over the internet.

We can see how financially profitable the work of a game producer is from young people who spend their dates and days in computer cafes. The game producer will definitely use the services of screenwriter , programmer, computer graphic artist, artist to explore the game. It also does the work of writing and reproducing the game on discs ,opening a site on the Internet, advertising, and so on. Current technical capabilities allow computer graphics to become popular, creating the conditions for natural output of images .The skill of the producer is that it will be difficult for the person who played the released games to get up from the computers. The computer enchants mankind.

The producer controls the ideas and goals in the games he creates. He also helps the children to learn various subjects by creating discs with producer's game-training programs. It is especially great for those who are learning foreign languages .manual-the discs went on sale.

4.Movie producer- in cinema, a trusted representative of a film company means an ideological - artistic and organizational-financial controller in the process of making a film. He is also actively involved in the selection of actors and technical staff. Director, actor, screenwriter is also can be produce. 
The world film industry is developing precisely due to the activities of producers. It is these people who make money for the expenses incurred in front of sponsors and investors .

The film producer comes up with the project, finds a good script and directors. Every produce has their own ultimate goal. He analyzes today's market and makes a plan for tomorrow . This is a direct risk.

What is the responsibility of a film producer ? First of all, the film producer must be able to calculate what the audience wants to see on the screen, what kind of film and how many viewers want to see the film. The producer then chooses a director and screenwriter who can make a film of a certain genre. Directs the playwriter's work in the script creating process. Once the script is completed, the producer will deal with the financial support. He appeals to state and non-state enterprises on this issue. Participating in the financing of a good film means the beginning of a filming campaign. In addition, the producer is actively involved in the selection of actors, film crew, artist and composer. But its main function is advertising and film distribution. Once the film is ready, the process of popularizing it begins. This process is carried out by the producer in three directions: it is offered to the heads of cinemas, TV companies and DVD makers.

5. Television producer. Nowadays it is impossible to imagine our life without television. Television is evolving day by day and making new technical achievements. The invention of digital television further improved the quality of television image transmission. Millions of people in our country watch TV programs. TV producers are divided into the following types:

- Chief producer (main producer) - gives the main idea, checks the work of other producers. As well as the work of an executive producer.

- Associative producer (associative producer) - performs limited production functions.

- Coordinating producer (producer-coordinator) - coordinates the work of several producers.

- Partner producer (so producer) - acts as a producer with the rest of the partner producer in the team.

- Executive producer (producer-executive) - supervises the work of the remaining producer, performs technical, organizational and financial work.

- Reference producer (linear producer) - manages the work of employees, solves technological and financial issues, creates a work schedule, does not interfere in the creative process.

- Website producer (producer of the website) - controls the management of sites. No matter what project the producer is working on, he or she must be professional and have sufficient knowledge and information.

In short, the prestige of the producer profession in the world of show business is high. If a producer is a master of his craft, the society, the show business industry, and the whole creative team will benefit from it. It creates the basis for the emergence of new projects in cinema, theater, television, concert programs, in any direction of the world of show business.

\section{REFERENCES}

[1] Sayfullaev B.S., Mamatkosimov J.A. "Acting skills". T.: Science and technology. 2012.

[2] Akhmedov F.E. "Fundamentals of directing public holidays." T.: "Communicator". 2008.

[3] Qoraboev U.X. "Holidays of the Uzbek people". T.: Editor-in-chief of Sharq Publishing and Printing Joint-Stock Company. 2002.

[4] Dushamov J. "Directing of public events". T. Gulom Publishing House of Literature and Art. 2002.

[5] Stanislavskiy K.S. "The actor's work on himself." Translation by T.Khojaev. Edited by S.Muhamedov. T. New adoptions. 2010

[6] Muhammad H. Basics of screenwriting. - Tashkent: Science and Technology, 2008.

[7] Umarov M. History of pop and mass performances. T.: "New Age Generation". 2009.

[8] Muhamedov M. "Fundamentals of Directing". T.: UDSI Publishing House. 2008.

[9] The skill of a film and television producer. Under. Ed. Ogurchikova P. M., 2009.

[10] Mahmudov J., Mahmudova X. "Fundamentals of Directing". T .: UDSI Publishing House. 2008.

[11] Sharifxo'jaev M, Abdullaev Yo. Management. T .: "Teacher" 2001.

[12] Basics of production. ed. Ivanova G. M .: UNITY. 2003.

[13] Yuldashev M. Synonymic Words in AbdulhamidSulaymonCho'lpon's Works. The International journal of analytical and experimental modal analysis. ISSN No:0886-9367. Volume XII, Issue VI, June/2020. PageNo: 1732-1739. 